\title{
Poverty Alleviation Strategies in Nigeria: The Missing Link of Adult Education
}

\author{
Olaniyi, Francis Oduola, D.Ed \\ Adult Education Unit, Department of Arts Education, Faculty of Education \\ Adekunle Ajasin University, Akungba Akoko, Ondo State, Nigeria \\ Email: francisolaniyi@yahoo.com \\ Aroge, Stephen Talabi (Ph.D) \\ Department of Arts Education, Faculty of Education, Adekunle \\ Ajasin University, Akungba-Akoko, Ondo State, Nigeria \\ Email address:draroge@yahoo.com
}

\section{Doi:10.5901/mjss.2014.v5n23p1674}

\section{Abstract}

Poverty eradication has attracted the attention of world body by making it as no 1 MDG. Poverty is seen as the condition of being poor and lacking in basic amenities of life. It is also psychological as poor people exhibit low self-esteem. This paper considered the missing link of adult education in poverty alleviation in Nigeria. Thus, it revealed that various strategies were employed by the government to reduce poverty in Nigeria. These include establishment of bodies to fight corruption and to empower people through skill acquisition. Infrastructural facilities were also constructed to curb poverty. Needless to state, adult education serves as a mechanism for poverty alleviation in that local people must partake in developmental activities for its sustainability and provision of continuing education for knowledge economy for workforce. Adult education and poverty alleviation go together because of various developmental changes that can occur on people and infrastructure. The concept of literacies for poor people should be imbibed by adult educators in order to reach various occupational groups in the society. Besides, all those theories and innovations could be implemented if the policy makers and decision takers are incorporated to adult education planning and implementation.

\section{Introduction}

The United Nations Decade for the Eradication of Poverty (1997-2006) is a global campaign for concerted action to ensure the effective reduction of poverty worldwide. UNESCO's role in this line in promoting the right to development and education can not be overemphasized. Education and training form perhaps the most important precondition for development. Citing The Dakar Framework of Action 2004, Preece and Singh (2005:1-2) state:

\footnotetext{
Education, starting with the care and education of young children and Continuing through life-long learning, is central to individual empowerment, the elimination of poverty at the house-hold and community level, and broader social and economic development. At the same time, the reduction of povertyfacilitates progress towards basic education goals. There are evident synergies between strategies for promoting education and those for reducing poverty. A multisectored approach to poverty elimination requires that education strategies complement those of the productive sectors as well as those of health, population, social welfare, labour, the environment and finance, and be closely linked to civil society.
}

Furthermore, one of the key Millennium Development Goals set by the United Nations in 2000 is: "eradicating extreme poverty and hunger". The target was to halve the proportion of people living in extreme poverty by 2015. These people are the ones whose income is less than one dollar a day. The year 2015 is close by, as it remains just few years. Going by the state of economy in the country and the economic activities of the individuals, how are we sure that Millennium Development Goal cited will be achieved?

Already, Nigeria sought and obtained debt relief from Paris club, World Bank and other creditor nations. Incidentally, there exists direct link between debt, poverty and development (Preece and Singh, 2005:2). With the debt relief obtained by the Federal Government, one expects that the fund used in servicing debts before then would be diverted to other projects which could be beneficial to the masses of the nation. Since 1999 when the civilian administration came on board, various poverty alleviation programmes have been embarked upon by all tiers of 
governments as well as private individuals and organizations. It is in the light of this that this paper titled "Poverty Alleviation Strategies in Nigeria: The Missing Link of Adult Education" is embarked upon. Towards this end, the role of adult education in poverty alleviation programmes in Nigeria, concept of poverty, poverty alleviation strategies in Nigeria, adult education as a poverty alleviation mechanism and the link between adult education and poverty alleviation programme among others are explored in the paper.

\section{Poverty}

The New Webster's Dictionary of the English language (2004) defines poverty as the condition or quality of being poor; while poverty line is seen as the marginal income level by which an adequate living standard is possible. Historically, according to Attiq-ur-Rahman (2005:31) poverty has been identified mainly in term of income level among the poor, or as a slow growth of GDP-Gross Domestic Product (GDP)-at the macro/national level. Thus,according to the scholar, international assessment of poverty depended heavily on income level as the basic measure of poverty. Today, the concept of poverty transcends this traditional definition as Poverty is now understood as lacking the basic means to live in dignity. Poverty manifests itself in various forms such as the lack of income and productive resources sufficient to ensure sustainable livelihoods; hunger and malnutrition; ill health; limited or no access to education and other basic services; increased morbidity and disease related mortality; homelessness and inadequate housing; unsafe environment; corruption and social discrimination (Preece and Singh, 2005:3). Looking at poverty from multi-dimensional perspective, it can be perceived as a human condition characterized by sustained or chronic deprivation of the resources, capabilities, security and power necessary for enjoyment of an adequate standard of living and other civic, cultural, economic, political and social rights.

Moreover, it is paramount to note that poverty may not have a uniform manifestation in all regions of the world.. In other words, poverty and its causes are context and regions specific. In urban and rural areas, the effect of poverty may not be the same while in an advanced economy the effect of poverty on people might not be as pronounced as in developing economy. Studies have shown that (Rogers, 2005; Preece and Singh, 2005; and Abadzi, 2005) the most vulnerable and marginalized groups are generally the female and the children. Poverty occurs, on many occasions, where inappropriate use of resources, national debt, corruption, war and conflict, gender inequality, poor governance, abuse of human rights, environmental degradation and exploitation of the market by advanced industrialized countries are the other of the day.

\section{Poverty Alleviation Strategies in Nigeria}

We have been able to establish above here to this paper that poverty is not only associated with income, but it may involve lack of self-determination, self-esteem, participatory democracy and good standard of living. In order to free people from poverty there is need for empowerment. Abadzi (2005:20) conceives empowerment as the process of increasing the capacity of individuals or groups to make choices and to transform in these choices into desired actions or outcomes. According to the scholar, empowering the poor should have a closer relationship with improving project performance and governance and growth that is pro-poor. Empowerment is thus seen as one of the top priorities in the fight against poverty. To that end, the Federal Government has been promoting increased access to basic services, better national, state and local government pro-poor market development, and access to justice.

Table 1: Some Poverty Alleviation Organizations in Nigeria

\begin{tabular}{|l|l|l|l|l|}
\hline S/N & Organizations & Period Established & Purpose of Establishment & Target \\
\hline 1. & Code of Conduct Bureau & During Military Era 1970s & $\begin{array}{l}\text { Declaration of assets by public and political office } \\
\text { holders, before and after leaving office in order to } \\
\text { determine individual wealth acquired }\end{array}$ & Individuals \\
\hline 2. & $\begin{array}{l}\text { Industrial Development } \\
\text { Centre }\end{array}$ & Military Era 1970's & $\begin{array}{l}\text { Promote small and medium scale industries } \\
\text { empowering the people }\end{array}$ & Groups and individuals \\
\hline 3. & $\begin{array}{l}\text { Economic and Financial } \\
\text { Crime Commission (EFCC) }\end{array}$ & $\begin{array}{l}\text { During military but } \\
\text { amended during civilian } \\
\text { administration (1999-2007) }\end{array}$ & $\begin{array}{l}\text { Fight against corruption among the public officers } \\
\text { in private and public establishments }\end{array}$ & $\begin{array}{l}\text { Government agencies and } \\
\text { civil, public and private } \\
\text { company workers }\end{array}$ \\
\hline 4. & $\begin{array}{l}\text { Independent Corrupt } \\
\text { Practices Commission (ICPC) } \\
\text { and other related commission }\end{array}$ & Civilian administration & Fight against corruption among public officers & $\begin{array}{l}\text { Government workers and } \\
\text { political office holder }\end{array}$ \\
\hline 5. & $\begin{array}{l}\text { SMEDA- Small and Medium } \\
\text { Enterprise Development } \\
\text { Agency }\end{array}$ & $\begin{array}{l}\text { Civilian administration } \\
1999-2003 \text { located in the } \\
\text { presidency }\end{array}$ & Promote small and medium business & Entrepreneurs \\
\hline
\end{tabular}




\begin{tabular}{|l|l|l|l|l|}
\hline 6. & $\begin{array}{l}\text { NAPEP-National Agency for } \\
\text { Poverty Alleviation } \\
\text { Programme }\end{array}$ & $\begin{array}{l}\text { Civilian administration } \\
1999-2003\end{array}$ & Reduce poverty in its forms & Individuals and groups \\
\hline 7. & $\begin{array}{l}\text { State Agencies for Poverty } \\
\text { Alleviation }\end{array}$ & Civilian Administration & $\begin{array}{l}\text { Promote small and medium scale industries, } \\
\text { empowering the people }\end{array}$ & Groups and individuals \\
\hline 8. & $\begin{array}{l}\text { National Directorate of } \\
\text { Employment (NDE) } \\
\text { Sure-P Scheme }\end{array}$ & $\begin{array}{l}\text { Military Era 1985-1993 } \\
\text { Goodluck Jonathan } \\
\text { Administration } \\
\text { 2011-2015 }\end{array}$ & $\begin{array}{l}\text { Train artisans, school leavers for the purpose of } \\
\text { empowerment } \\
\text { Plowing back back subsidy removal on projects } \\
\text { which have impacts on the people- skill } \\
\text { acquisition, job creation, women } \\
\text { empowerment,and other projects }\end{array}$ & $\begin{array}{l}\text { Groups and individuals } \\
\text { Construction of roads, } \\
\text { individuals and } \\
\text { organisation }\end{array}$ \\
\hline
\end{tabular}

Sources: (1.) National Bureau of Statistics (2008) Annual Abstracts of Statistics, Abuja: Federal Republic of Nigeria. ( 2. )AChild Nssien, A (2013) Sure-P Scheme: of Circumstance? Daily Independet http://dailyindependentnig.com /2013/02/sure-p-scheme-a-child-of-circumstance/

In Table 1, one observes the strategies employed by the government in order to ensure good governance, transparency, and accountability, distribution of wealth, empowerment of the poor, justice and curbing corruption. All these programmes are targeted at the people so that poverty would be eliminated in our society. In the history of this country, for instance, we have never heard where a military governor or military administrator was tried for corruption. However, many cases of corruption have been preferred against civilian governors and other functionaries in this civilian dispensation. Whether that act is serving as a deterrent for others is a different thing. Nevertheless, this may likely be an indication that democracy is better than any other forms of governance.

Furthermore, the sure-p scheme was introduced by the Jonathan administration as a result of removal of subsidy on petroleum (Nssien,2013). The money realized from subsidy removal is to be spent on projects that have direct positive impacts on members of the public. These include skill acquisition, youth and women empowerment, job creation, construction of roads, rehabilitation of public moribund infrastructure, provision of housing and health, and meeting the millennium development goals agenda (MDG). The introduction of sure-p however led to the abolition of NAPEP.

Table 2: Some Activities of Government Poverty Alleviation Agencies

\begin{tabular}{|c|l|l|l|l|}
\hline S/N & Types of Project & Procedure for Execution & Recipients & Remark \\
\hline 1. & Road construction rehabilitation & Counterpart funding & Members of community & \\
\hline 2. & Classroom rehabilitation and building & Counterpart funding & Schools and children & \\
\hline 3. & Culvert construction & Counterpart funding & Community & \\
\hline 4. & Stream channelization & Counterpart funding & Community & \\
\hline 5. & Skill acquisition & Full funding & Individuals & \\
\hline 6. & Community Development Projects & Counterpart funding & Community & \\
\hline 7. & Tax relief and stoppage on certain items & Non-collection of custom duties & People in the country & Done by Nigeria custom \& exercise \\
\hline
\end{tabular}

Source: Research Data, March 2013

The activities of these agencies range from improvement of infrastructural facilities, environmental sanitation, health provision, availability of food and shelter to human resources development. One observation that should be made is that although the focus of these agencies is on the poor people, it appears that the rich people and middle level income earners benefit most. How do we now take care of the low income earners and the poor? This is where adult education, especially literacies, as advocated by Rogers (2005:60) come in.

Table 3: Non-Governmental Organizations Poverty Alleviation Activities

\begin{tabular}{|c|l|l|l|l|}
\hline S/N & Types of Project & Procedure for Execution & Recipients & Remark \\
\hline 1. & Purchase of building materials & Loaning money to people & Individual members & $\begin{array}{l}\text { Not for non- } \\
\text { member }\end{array}$ \\
\hline 2. & Purchase of house-hold utensils & $\begin{array}{l}\text { Either purchased for members or giving } \\
\text { money to members }\end{array}$ & Individuals & \\
\hline 3. & Children school fees and family needs & Obtaining loan from cooperative societies & Individual members & \\
\hline 4. & $\begin{array}{l}\text { Establishment of small business companies and } \\
\text { extra-earning }\end{array}$ & Obtain loan & Individual members & \\
\hline 5. & Skill acquisition & Full funding & Individuals & \\
\hline
\end{tabular}

Source: Research Data, March 2013 
One may likely say that the non-governmental organizations focus mainly on the improvement of standard of living of the poor. This is reflected in some of their activities as depicted in Table 3. Both workers in formal establishments (government workers) and those in informal sectors of the economy benefit from one kind of poverty alleviation programmes or the other. The question is: Are the artisans, roadside workers, traders aware of these poverty alleviation programmes? How do they access these poverty alleviation programmes, given their supposed low esteem?

\section{Adult Education as a Poverty Alleviation Mechanism}

Preece and Singh (2005:4) identify three distinct forms of adult education: formal, non-formal and informal. Formal education is usually learning that leads to certification. It can be part-time or full-time, but it is always institutionally based. Non-formal education, according to these scholars, refers to the range of targeted learning opportunities that are offered outside educational institutions which are however organized to achieve particular learning outcomes. Examples of this form of adult education include: work-based skills training, education, workshops and any other specific learning programme. Informal adult education is often connected to projects in which education is not the main priority, but which result in increased knowledge, skills and understanding. The tailors, welders, hair dressers, phone call business, farmers, traders and the rest need a variety of literacy which is peculiar to their occupations . No wonder why Rogers (2005:60-62) advocate the provision of relevant literacies in order to empower these categories of workers.

There is no doubt adult education is about empowerment, and ultimately poverty reduction/alleviation is also about empowerment. Both involve issues of sustainability, participatory control, the use of indigenous knowledge systems, local governance and development. Citing Swiss Agency for Development co-operation, Preece and Singh (2005:5) writes:

Empowerment includes giving power Or entiflement to people, helping people Acquire capabilities or qualifications, Establishing structures which enable Individuals and groups to have more Control over decisions that affect them, giving people voice and Skills to access and utilize what they are entitled to.

Thus using adult education to reduce poverty is an enabling process combining adult education with other initiatives, as seen in Tables 1 and 2, builds capacity for self-advocacy.

Furthermore, Easton, Sidikou and Crouch (2005:14) justifies adult education as a poverty alleviation technique in two ways. First, the developmental activities in health, agriculture, management of school system, public administration can only be effective and sustained if they are taken over and directed by local beneficiaries and their institutions. Second, the challenges created by urbanization, industrialization and the movement from low to middle income status led to what is termed as "continuing education for a knowledge economy". That is upgrading the skills and knowledge of a workforce that may have basic education, but not at present either the technical competence or the self-directed learning capacity to turn informal sector enterprises into locally and regionally competitive industries. Transformation of this kind is unimaginable without the support of good adult education and training.

\section{The Link Between Adult Education and Poverty Alleviation Programme}

The poor and the powerless are capable of discontent, but they are not always able to organize themselves to demand social justice (Bhola, 2004:13); they need help from selfless teachers and activist. In the present context and conditions in the developing and the developed world, adult education and adult educators seem to be the best hope for the world's poor. Unfortunately, despite the fact that adult educators understand the efficacy of adult education in poverty alleviation, they are only at the stage of offering dialogue and discussion on development at conferences, seminars and workshops. This calls for being more active and combining adragogy with politics so that adult educators can help the poor.

Atiq-ur-Rahman (2005:34) studied poverty and adult education in Pakistan. He finds out that adult education impacts in a number of ways on the reduction of poverty

(i) It improves the overall development of the country.

(ii) Children stay longer in school system when, they have parents who are literate. Illiterate parents often do not see the longterm benefit of sending their children to school.

(iii) Literate adults become more involved in local development schemes, such as water management, cooperatives and micro-credit schemes.

(iv) Literate adults are more likely to seek and use legal support.

(v) Literate women become more confident in living their lives, forming groups, taking on leadership roles and improving the quality of their lives and that of their children's. 
(vi) It positively affects health indicators such as material mortality, immunization and potia eradication.

(vii) It helps people to become aware of their rights and responsibilities.

In addition Bhola (2004:18-23) opines that adult education is linked to poverty reduction at various levels of human interaction: global, national, provincial/state, district, community and family levels. Adult Education ensures world peace through aggressive tasks of nation building across the world, poverty reduction, arresting HIVIAIDs and other diseases, and the education of adults (including children). Adult education provided to urban and rural dwellers brings about redistribution of wealth, using appropriate technology, and modernization to the dwellers in both places.

Adult Education and poverty reduction at the state and local levels have to become indigenous, using alternative concepts of development, and new definitions of poverty.

While the NGOs-Non governmental organizations-encourage the development of local adult education institutions at the community and school levels. Bhola (2004) notes, that most of the families in the world are male headed, and the male is considered the bread winner, irrespective of the contribution of the female in growing and preserving food. The females in the household are kept "poor" because in many cultures they are not allowed to inherit property. They are disadvantaged in may other ways. With a worldwide chorus of voices in favour of women's development, adult education can help for poverty reduction among women, presently living in double jeopardy.

\section{Recommendations and Conclusion}

Adult Education may only work in poverty reduction and lead to sustainable development if we think of the condition of poverty in relation to political, economic and social arrangement imposed on us by the circumstances of colonialism. Similarly, the trends around the world, especially the world bodies' effort in reducing poverty all over the places through various programmes like MDG and the likes may also put adult education in the perspective of reducing poverty.

Adult educators and the educational institutions where adult education is offered at certificate, diploma and degree levels have to be proactive by not relying on talking alone but embracing programmes, actions and politicking that may make adult education help reduce poverty. Furthermore, the following suggestions are made.

(i) Ensure information, sensitization and orientation for decision-makers and key people so that major innovations in adult education are not likely to stop at the doors of conferences and workshops. Thus it would reach the level of implementation.

(ii) Poverty is a multifaceted phenomenon. It needs involvement of relevant ministries and agencies. Therefore, all hands must be on deck to plan for a comprehensive programmes on adult education and poverty alleviation.

(iii) Its high time we employed the use of Participatory Rural Appraisal so that the target groups and their communities in rural areas will be reached through adult education programmes.

(iv) Adult Educators are to approach the teaching of literacy from the perspective of literacies in order to take care of various occupational groups such as barbers, vulcanisers, religious preachers, tailor, etc.

(v) Whenever literacies are to be organized, linking it with credit and enterprise supporting institutions would attract participants from the people. This underscores the knowledge of assistance institutions by the adult educators.

(vi) The sure-p scheme and other related agencies need to bear in mind to incorporate literacy programme so that members of the public will benefit maximally from such ventures

\section{Conclusion}

Adult learn through doing, not in preparation for doing. Adults can learn encompassing occupational literacies without first attending schooled literacy obtained in schools. That is why all efforts are to be made to focus adults, especially those at the lower rung of the ladder so that poverty would be reduced or totally eradicated from our society.

\section{References}

Abadzi, H. (2005) "Adult illiteracy, Brain Architecture, and Empowerment of the Poor" Adult Education and Development 11ZDVV 65, 1934.

Attiq-ur-Rahman, S (2005) "Poverty and Adult Education: The Experience Pakistan". In: Preece, J and Singh, M(ed.) Adult Learning and Poverty Reduction Hamburg: UNESCO Institute for Education.

Bhola, H.S (2004) "Adult Education for 'Poverty Reduction: Political Economy Analysis from a systems Theory Perspective" Adult Education and development, 11ZDVV 64, 13-24. 
Easton, P. Sidikon, M, and Crouch, L (2005) "Adult Education and Poverty Reduction: consolidating the Link". In : Preece. J and Singh M. (ed.) Adult Learning and Poverty Reduction. Hamburg: UNESCO Institute of Education. PP 14-16.

Onyishi, J.C (2004) "Eradication of poverty through Women's participation In Pieck, Enrique (2005) Adult Learning for Sustainable livelihood and it Relationship to Basic Education and Basic Skills for All. Adult and Non-Formal Education: A study of Nsukka in Enugu State of Nigeria" Adult Education and Development

Rogers, A. (2005) "Literacy and Production Skills Training Embedded Literacies" in Adult Education and Development 11ZDVV 65, 5966

The New Webseter's Dictionary of the English language (2004) International Education, New York Lexicon Publications, Inc.

Sandhaas, B (2005) "Community Based Non-Formal Livelihood Skills Training for Youth and Adult in Selected Regions of Ethiopia" Adult Education and Development, 11ZDVV 64, 55-57.

National Bureau of Statistics (2008) Annual Abstracts of Statistics, Abuja: Federal Republic of Nigeria.

Nssien, A (2013) Sure-P Scheme: a chid of Circumstance? Daily Independet http://dailyindependentnig.com/2013/02/sure-p-schemea-child-of-circumstance/ Accessed June 9, 2014. 